UDC 378.147:78

DOI: $10.36550 / 2415-7988-2020-1-190-38-42$

RASTRYGINA Alla Mykolaivna -

Doctor of Pedagogical Sciences, Professor of the Department of Music Art and Methods of Music Education Central Ukrainian State Pedagogical University Volodymyr Vynnychenko ORCID:https://orcid.org/0000-0002-4393-2831 e-mail: rastrygina.alla@gmail.com

\title{
TRAINING OF FUTURE SPECIALISTS-MUSICIANS ON THE PRINCIPLES OF INTERDISCIPLINARY MODELS OF FREE ARTS
}

Formulation and justification of the relevance of the problem. In the context of the proposed innovations related to the implementation of the Law of Ukraine «On Higher Education», the main educational task of today is the integration of the national higher education institution into the world system of higher education institutions of different levels of accreditation, active interaction with the international pedagogical community, introduction of perspective interdisciplinary innovations focused on the development of educational systems, ensuring access to high quality higher education, due to mobility of university graduates in the labor market; introduction of flexible educational programs and information technology training in accordance with the Bologna Declaration.

Therefore, the functioning of the higher education system in accordance with European requirements should ensure the autonomy of higher education institutions, combining education with science and production in order to prepare a competitive specialist for high-tech and innovative development of the country, self-realization of a personality, providing the society, labor market and the state with skilled professionals [4].

In view of the above, special attention is needed to the system of professional art education, which, functioning in the range of problems of such systems of organization of human activity as culture, art, education, has always been and remains an organic, integral and independent part of the phenomenon of Ukrainian culture, which is an integral part of both European and world cultures as a whole.

Professional artistic, and, in particular, music education based on the principles of a humanistic, personality-oriented paradigm, though, as stated, aimed at training a competent specialist, ready to bring up an educated, spiritually rich young person by peculiar means and ways inherent only in musical art, yet, in the context of today's requirements, it needs some refurbishment. Moreover, as stated in the legislative documents, in order to catch up with the civilized world, which is very changeable today, and educational trends are developing continuously, it is necessary not only to keep up and move at an accelerated pace, it is necessary to act like a lightning [3].

Thus, the reforming of professional arts education in line with European and global dimensions leads to a rethinking of sustainable approaches to the professional training of future music professionals.

Analysis of recent research and publications. Considering contemporary approaches to professional art education, M. Chemberzhy emphasizes that constant and direct communication with the arts should be its conceptual basis, which enhances its natural beneficial influence on a personality many times. Deep «immersion» in art becomes a natural way of self-expression for students, a defining feature of the individual perception of the educational process. It is the latter that should provide each of them with a wide choice of opportunities for acquiring knowledge, for daily self-realization in a constant process of enrichment and deepening of professional skills, for the forming of skills to actively seek and find information, to acquire professional experience. According to him, «... student youth receives creative force and inspiration, hope and optimistic desire to live and create in the process of communicating with the arts, to experience, daily, the growing force of active integration into the artistic educational space...» [6, p. 70].

According to S. Volkov, the solution of the problem of integration of higher education, and art education, in particular, into the world educational space, requires the provision of high quality professional training, synthesizing progressive domestic and foreign experience and the latest scientific achievements aimed at training a highly professional specialist with broad professional background, armed professionally and technically, talented and creative, fanatically committed to the arts, capable of scientifically-pedagogical, creatively performing, art-public and culture educational 
activity [3].

According to V. Kremen [5], the urgent need in creating conditions that would truly allow the universities, teachers and students to fully discover and realize their innovative educational and professional potential, stipulates the need to finally get rid of still existing in science and education management system declarativity, rigidity and insularity from any innovations left to us by the Soviet system and which, despite the titanic efforts of domestic scientists, university teachers and practitioners, in many respects still interferes with its integration into the world educational processes.

So, today, there is an urgent task for the professional music education, - to finally abandon traditional experience of the Soviet higher education, which was focused on excessive encyclopedic teaching, and proved to be undue for modern realities. The task of modern higher education should be to prepare a really competent in his or her job musician, capable of self-development, self-expression and self-realization in personal professional activity.

The purpose of the article is to outline the possibilities of reconstruction of professional development on the basis of the introduction into the content of professional training of a future specialist musician the principles of interdisciplinary models of free arts which are effectively used in the world educational practice.

The main material of the study. Our scientific stance on reforming the existing system of training future music professionals is linked, above all, to a broader vision of the sociocultural purpose of contemporary professionals in the field of art. This causes a reassessment of values in the system of traditional perception of the tasks of art education and should ensure not only the acquisition of the competencies of a specialist musician by the student audience, but also turn musical art into a means of becoming and developing a personality of a future specialist as the author of his own life and professional activities.

Therefore, the content of professional training requires some reconstruction on the basis of the formation and development of subjective features of a future musician. That is, in addition to defining the professional competencies that make up the essence and specificity of the profession and determining the expected results of the educational process, which an art training graduate must possess, the inclusion of an individual orientation of each student's abilities, opportunities, needs, preferences in the range of directions of the chosen specialty must be compulsory in the content of his or her professional training, to our mind. We believe that such a combination will provide effective training of modern specialistmusician of a wide profile and may become the basis of his or her inner spiritual and creative self-development and self-expression, selfrealization, free choice of individual trajectory of professional and creative development.

One of the quite effective educational systems, based on the principles of free selfdetermination of a personality and successfully implemented in many American and European Universities, is the model of Liberal Arts and Sciences, the essence of which is the introduction of balanced and built on the best international experience of bachelor's - master's - and doctor's programs; an organic combination of the teaching and research work; focusing on basic international standard training courses that give a broad background in the profession, nurture a culture of thinking and allow the specialist to respond flexibly to the needs of the labor market; selection of gifted youth to study; formation of spiritual environment; creatively adapted use of international achievements in the field of organization of educational process, modern educational technologies.

Since higher education around the world, and in Ukrainian, in particular, is facing new challenges today, from the cost of education and the emergence of new technologies to the problems of the relationship between university education and employment prospects [2], many scholars and higher education professionals are turning to experiments with the aforementioned model of study. Over the past decades, in some universities in Ukraine the scientists and educators have made attempts to adopt the components of the Liberal Arts model to their own educational environment. And the flagship of full-scale implementation of the system of professional training of future specialists on the basis of Liberal Arts Education has been and remains the Kyivo-Mogylianska Academy, which is always at the forefront of reforms. But at the same time, this practice also takes place at the department of vocal and choral disciplines and methods of musical education of the Volodymyr Vynnychenko Central Ukrainian State Pedagogical University.

As active supporters of the rapid expansion and combination of scientific and professional components in the system of professional art education, we support D. Becker's view on modern higher education, that the combination some models of liberal arts, and in particular, 
the Liberal Arts and Liberal Arts and Sciences is especially significant. Therefore, the Liberal Arts and Sciences model of education, with its inherently flexible student-centered curriculum, combines the breadth of disciplinary coverage with the depth of study of professional disciplines, encourages the multitude of interspecialty connections, and provides students with the greatest possible freedom of choice. In our view it can become an effective means of reconstructing the professional training of a future specialist-musician.

It should be noted that in modern international practice there is a large number of state universities, where the training of future specialists is based on the classical system, but they also offer quite successful educational programs that implement the model of Liberal Arts and Sciences. According to D. Becker, this approach works particularly well in countries where education reforms are underway, since it «enables reformers to organize modern educational structures that implement the model in already existing educational institutions» [2].

An example of reconstruction of professional development of a future music specialist in the context of the required reform processes may be the coexistence and even the productive interaction of the «Liberal Arts and Sciences» model with the traditional system of education in some institutions of higher education in the United States. Such interaction is aimed at the development of creative, critical and independent thinking of future musicians, intensification of their research activity, enabling them to test themselves as specialist, already participating in the educational process, due to introduction of the latest forms and methods of teaching and due to elaborate network for their practical activities.

The American scholars research on the professional and personal characteristics of a modern specialist-musician [8], focuses on such essential features as student's musical and intellectual development, leadership skills, professional responsibility, efficiency and excellence of teaching, mastering the innovative methods of studying, developed skills of effective use of academic time, the outline of strategies for work in classroom and at home, forming of interpersonal relations, managing one's own behavior and the activities of the learners. These characteristics correspond to the basic principles and objectives of the «Liberal Arts and Sciences» model and have a significant effect on the content of professional training of future specialists-musicians.

This is reflected in the streamlining of the content and structure of subject and methodological courses on an interdisciplinary basis, the use of innovation and feedback in classroom and extra-curricular work, the application of modeling techniques, computer and multimedia technologies and more. Along with the courses that traditionally take place in training of a future specialist-musician, there are integrated courses aimed at advanced study of professional disciplines; various scientific studies of the major (instrumental, vocal-choral, etc.) field are compulsory; emphasis is placed on students' research activities, the interdisciplinary studies are conducted, on the interconnection and interaction of different arts and cultures, current issues of development of philosophy of education and art are studied.

Regarding the improvement of professional training programs, the process of acquiring professional competencies for students in a specially organized artistic environment could serve as an example. For instance, in the training program of future music teachers on vocal specialty (Voice major) [7], the compulsory courses are individual and choral vocal, choral conducting, participation in opera scenes, etc. It is also mandatory to acquire the skills of singing songs in original language, so students can opt to take any language course to study Italian, French, Spanish or Russian.

Each Faculty of Music Education has its own opera where students are prepared for two semesters for staging and performing in the opera, which is evaluated as an exam. All students are required to participate in choirs, marching bands, where they play the instrument that matters to them and take part in chamber ensembles of 3-5 persons (chamber music).

The performing activity of students who study in the field of music education is of great importance for their future professional career. One hour a week of the curriculum time is set aside for the students of any professor class (studio-class) to do a solo performance (as in a concert) and its subsequent public discussion, where the teacher and each one of the students provide their comments, suggestions, and recommendations.

It is compulsory for students to have departmental performances as well as out-ofuniversity performances. That is why most students organize their own lectures, concerts and speeches on the radio, in churches, children's and charity homes, etc. It is in this way that a future specialist demonstrates their professional and pedagogical competences, which is a prerequisite for future employment.

Interesting is the experience of organizing a piano program for non-pianists, conducted twice a week in specialized laboratories, equipped 
with computers and 16-20 electronic instruments with the main instrument for the teacher. All the instruments are connected to a teacher's control panel, and the teacher, with headphones and a microphone, works with each student individually or unites them into small groups, listens and evaluates the work of each. This course is compulsory for undergraduate music students and is taught over four semesters with an exam after each. If a student has not passed the exam in any semester, he or she is obliged to take this course again from that semester.

In a specially equipped computer lab, students take music theory and music composition courses, which are now very prestigious and in demand. A music composition course, which can only be taught by a professor with a qualification in two fields: composition and music technology is compulsory, for example, at the University of Nebraska-Lincoln. The mastering of such a course gives a future specialist not only the skills of composition, but also the ability to organize and record the concert performance of any performer or collective without recourse to specialists in music technologies.

All students, without exception, have their own websites and e-mail addresses in the university network. The portal of each of them contains information on the chosen specialty or specialization, name of the courses a student is enrolled in and in which semester; course work program, class schedules, classroom numbers, teachers' names, etc. are provided.

Most teachers take on-line assignments, coursework, and other online work and place high demands on the dynamics of such presentations, though some remain supportive of evaluating students for print versions. This approach to the organization of the educational process saves personal time of both, a teacher and a student. Perhaps that is why, with the wide range of courses and disciplines that a future musician should master, students have time to attend concerts, exhibitions, festivals, as well as ample opportunities for leisure activities.

Conclusions and prospects for further researches of direction. Reflecting on the possibilities of reconstructing the professional training of future musician specialist in the context of modern reformation processes, we have come to conclusion that education in accordance with models of free arts and in particular Liberal Arts and Liberal Arts and Sciences models has positive influence on the tasks of effective training of modern specialist, which is in demand in today's society.
Based on the teacher's orientation towards students, flexible curriculum, broad disciplinary coverage and depth of subject study, interconnection of disciplines and freedom of choice of courses, the Free Arts models determines the solution of certain problems in the university education system, in particular, the crisis of disciplinary specialization; academicism and an excess of lectures; lack of partnership between teachers and students, detachment of theory from practice; inability of students to think critically and freely [1].

The introduction of innovative educational programs for professional development of future specialists-musicians, who are targeted at student development and able to implement the Free Arts and Sciences model in the art educational space of universities, is one of the ways of successful reform of music education in Ukraine.

\section{СПИСОК ДЖЕРЕЛ}

1. Авдонина Н. С. Образовательная модель Liberal Arts: содержание и методы // Ценности и смыслы. 2017. № 4 (50). С. 98-105.

2. Беккер Д. Что такое либеральное образование и чем оно...не является // Проблемы либерального образования. Сборник статей. СПб. 2012. C. 20.

3. Волков С.М. Мистецька освіта в реаліях соціокультурних процесів// Культура України. Випуск 35. 2011. С. 42-49.

4. Закон України «Про вищу освіту». Режим доступу: https://zakon.rada.gov.ua/laws

5. Кремень В. Г. Почему мы бедные, если такие образованные? «Зеркало недели. Украина» №6, 20 февраля 2015. С. 4-9.

6. Чембержі М. І. Міжнародні творчі зв'язки як спосіб оптимізації мистецької освіти / M. I. Чембержі // Взаємодія культур і збереження розмаїття форм культурного самовираження в умовах глобалізації : матеріали Міжнар. наук.практ. конф., м. Київ, 28-29 трав. 2013 р. К., 2013. C. $69-71$.

7. Jordan, J. Wyers, G. Music for Conducting Study. G I A Puns 2009. 213 s.

8. Conway M, Colleen M., Thomas M. Teaching Music in Higher Education. New York: Oxford University Press. 2009. 311 s.

\section{REFERENCES}

1. Avdonina, N. (2017). Obrazovatel'naya model' Liberal Arts: soderzhanie i metody. Tsennosti i smysly. [Educational model of Liberal Arts: content and methods. Values and meanings].

2. Becker, D. (2012). Chto takoe liberalnoe obrazovanie i chem ono ... ne yavlyaetsa. Problemy liberalnogo obrazovania. [Becker D. What is liberal education and what it... is not. Problems of liberal education].

3. Volkov, S. (2011). Mystetska osvita v realiakh sotsiokulturnikh protsesiv. Kultura Ukrainy. 
[Art education in the realities of socio-cultural processes.Culture of Ukraine] .

4. Zakon Ukrainy "Pro vyschu osvity» (2018). [Law of Ukraine «On Higher Education»].

5. Kremen', V. (2015). Pochemu my bednye, esli takie obrazovannye?. Zerkalo nedeli. [Why are we poor if we are so educated? Mirror of the week.].

6. Chamberzhi, M. (2013). Mizhnarodnyi tvorchy zvyazky yak sposib optymyzatsii mystetskoi osvity. [International creative relations as a way to optimize art education]. Kyiv.

7. Jordan, J., Wyers, G. (2009). Muzyka dlya dyryhent $s$ 'koho navchannya [Music for Conducting Study].

8. Conway, M., Colleen, M., Thomas, M. (2009). Vykladannya muzyky u vyshchiy osviti. [Teaching Music in Higher Education]. New York.
ВІДОМОСТІ ПРО АВТОРА

РАСТРИГІНА Алла Миколаївна - доктор педагогічних наук, професор кафедри музичного мистецтва та методики музичної освіти Центральноукраїнського державного педагогічного університету імені Володимира Винниченка.

Наукові інтереси: теоретичні та методологічні основи професійної художньої освіти в Україні та за кордоном.

\section{INFORMATION ABOUT THE AUTHOR}

RASTRYGINA Alla Mykolaivna - Doctor of Pedagogical Sciences, Professor of the Department of Music Art and Methods of Music Education Volodymyr Vynnychenko Central Ukrainian State Pedagogical University.

Circle of scientific interests: theoretical and methodological foundations of professional art education in Ukraine and abroad.

Стаття надійшла до редакиії 06.11.2020 p.

РЯБОВОЛ Лілія Тарасівна доктор педагогічних наук, професор, професор кафедри державно-правових дисциплін та адміністративного права Центральноукраїнського державного педагогічного університету імені Володимира Винниченка ORCID: http://orcid.org/0000-0003-3558-2103 e-mail: lryabovol8@gmail.com

\section{КРЕАТИВНІСТЬ ЯК ПРЕДМЕТ ПСИХОЛОГО-ПЕДАГОГІЧНИХ ДОСЛІДЖЕНЬ ВІТЧИЗНЯНИХ ВЧЕНИХ}

\begin{abstract}
Постановка та обгрунтування актуальності проблеми. Соціально-
\end{abstract} економічні та соціокультурні умови сучасного етапу розвитку України і світу значною мірою детермінуються загрозами й викликами глобального характеру. Від того, наскільки особистість спроможна відповідати на них, залежить іiі успішна адаптація і соціалізація. Необхідними й потрібними наразі стають не стільки знання, скільки вміння на основі отриманої інформації проводити аналіз подій, явищ та процесів, які відбуваються у навколишньому світі, передбачати i прогнозувати їх, використовувати відповідні результати для вирішення проблем різного характеру не лише стандартними, але й неординарними способами. У свою чергу, це вимагає принципового оновлення типу мислення, що уможливить генерування особою ідей, оригінальних рішень. Відповідний комплекс умінь і навичок, за умови їх сформованості в особистості, позначає іiі як креативну, творчу. Саме така особистість є затребуваною в різних сферах життя та діяльності суспільства i держави. На креативного професіонала очікують сьогодні у різних галузях народного господарства, в органах державної влади та органах місцевого самоврядування. Очевидно, що його підготовку може забезпечити лише креативний викладач 3 творчим підходом до організації процесу навчання. Відтак, креативність, ії розвиток та умови, що його забезпечують, - комплексна проблема, яка у зв'язку зі своєю актуальністю притягує до себе значний науковий інтерес.

Аналіз останніх досліджень i публікацій. Креативність

міждисциплінарна проблема, саме тому вона $\epsilon$ у колі уваги фахівців 3 різних галузей знань. Особливий інтерес вона викликає у представників психологічної та педагогічної наук. 3 відповідних позицій досліджували розвиток креативності у дошкільників (В. Л. Антонішина, С. В. Лозинська, В. В. Маршицька, Л. М. Михайлова, В. В. Фалько, Л. М. Шульга та ін.); в учнів 